\title{
Ecophysiology of seed germination in Mediterranean geophytes. 1. Muscari spp.
}

\author{
Maria A. Doussi and Costas A. Thanos* \\ Department of Botany, Faculty of Biology, University of Athens, Athens 15784, Greece
}

\begin{abstract}
Ecophysiological aspects of seed germination were investigated in four Mediterranean geophytes of the genus Muscari (Liliaceae): M. comosum (tassel hyacinth), $M$. neglectum (common grape hyacinth), $M$. commutatum and $M$. weissii. Experiments were performed at constant temperatures in the dark and under temperature and light conditions simulating those prevailing in nature during November-January, i.e. well into the rainy season of the Mediterranean climate. In all species, no primary dormancy was revealed, and germination occurred in a rather narrow range of cool temperatures (optimum at 10 or $15^{\circ} \mathrm{C}$ ) and at a remarkably slow rate; both germination characteristics seem to be associated with autumn/winter seed germination and seedling establishment. Such a postulated strategy is ecologically advantageous within an unpredictable rainfall regime, known to prevail during the start of the rainy period of the Mediterranean climate. This strategy may also explain the spread of germination of $M$. comosum seeds over two consecutive years, observed by Theophrastus. Far-red light, simulating light conditions under a dense canopy, resulted in only a slight delay of germination compared to dark controls. Diurnal white light, qualitatively simulating natural daylight, caused a significant decrease of the germination rate in all four species studied. Moreover, white light was found to suppress considerably final seed germination (photoinhibition) in $M$. weissii and $M$. neglectum; in the latter species, prolonged imbibition under white light also led to the induction of secondary dormancy.
\end{abstract}

Keywords: common grape hyacinth, fire, germination rate, light, Liliaceae, Mediterranean geophytes, Muscari commutatum, Muscari comosum, Muscari neglectum, Muscari weissii, photoinhibition, secondary dormancy, seed coat, seed germination, tassel hyacinth, temperature

\footnotetext{
*Correspondence

Fax: +30-10-7274702

Email: cthanos@biol.uoa.gr
}

\section{Introduction}

Muscari (grape hyacinth), a genus comprising four subgenera and c. 40 bulbous perennial species, grows mainly in the Mediterranean region, but its area of distribution extends into Russia and Iran. The name Muscari derives from the Arabian word 'muscarimi', which in turn originates from the Greek word 'moschos' referring to the fragrance emitted by certain species. Two of the species investigated in the present study, Muscari comosum (L.) Miller and Muscari weissii Freyn belong to the subgenus Leopoldia (Parl.) Rouy while the other two, Muscari neglectum Guss. ex Ten. and Muscari commutatum Guss., belong to the subgenus Botryanthus (Kunth) Rouy (Davis and Stuart, 1984).

M. comosum (tassel hyacinth) is a distinctive, widespread plant, easily recognized by its purple or electric-blue 'tassel' made of small infertile flowers with long stalks. The fertile flowers are brown with pale yellowish-brown teeth. The species is a Mediterranean element and the most variable one in the subgenus Leopoldia; it grows from sea level up to $2000 \mathrm{~m}$ and is distributed over south-western and central Europe, the Mediterranean area and eastwards to Iran and Arabia. In some regions, especially Greece, the edible bulbs are still collected from the wild and can sometimes be seen in local markets.

M. weissii is similar to M. comosum but the teeth of the fertile flowers are yellowish. The species is an eastern Mediterranean element and grows from sea level up to $800 \mathrm{~m}$ in the Cyclades, the eastern Aegean islands, Crete and south-western Anatolia.

$M$. neglectum (common grape hyacinth) is a widespread polymorphic species. The uppermost flowers are usually light blue, small and sterile, whereas the flowers below are blackish blue with white recurved teeth. It grows from sea level up to $2300 \mathrm{~m}$ in northern Africa, Europe and western Asia.

M. commutatum is very similar to $M$. neglectum, but has fragrant flowers with blackish-violet teeth. It is an eastern Mediterranean element and grows near sea level in Italy, Sicily, the Balkans and the Aegean. 
Theophrastus (4th century BC) in both his plant treatises [Historia Plantarum (HP) and De Causis Plantarum $(C P)]$ refers numerous times to $M$. comosum, known as 'bulbs' (which is still the current vernacular name of the plant in Greece). The plant is accurately described (e.g. HP 1.10.7; HP 7.13.1; see also Negbi, 1989), perhaps the consequence of its importance as a food source and its apparent cultivation. Indirect support for the latter are Theophrastus' passages about a method to increase the size of the edible bulb (HP 7.12.2) and the 'paradox' of seeds that germinate in two consecutive years: 'It is a characteristic of "bulbs" that not all seeds germinate together but some this year and the rest during the next (season), similarly to, as they say, the aegilops, trefoil and sugar beet' (HP 7.13.5; CP 4.6.1).

In regard to seed dispersal, $M$. comosum and $M$. neglectum are described as rain ballists and anthropochorous (Müller-Schneider, 1986), while the latter species is additionally referred to as myrmecochorous (Müller-Schneider, 1983).

Little information is available on the germination of geophytes (Baskin and Baskin, 1998). Apart from karyological and cytotaxonomical studies on the genus Muscari (Bentzer, 1969, 1972a, b, 1973; Stuart, 1970; Garbari, 1984; Karlén, 1984; Dalgic, 1991), information concerning the overall reproductive biology of the studied taxa is scarce (Valdés and Mejias, 1988).

The present study is a contribution towards filling this gap of knowledge and investigates the ecophysiology of the germination behaviour in four Mediterranean species of Muscari. More specifically, the following aspects are examined: (1) germination in the dark and dormancy status of the seeds; (2) temperature range and rate of germination; (3) germination characteristics under simulated natural conditions; (4) the role of light (and seed coat) on germination; and (5) the potential induction of secondary dormancy.

\section{Materials and methods}

\section{Plant material}

Seeds of M. comosum and M. neglectum were collected in July 1991 from a burned pine forest at Mt. Parnes, Attica [400-450 m above sea level (a.s.1.)] during the second postfire year (Thanos et al., 1996). The seeds of M. neglectum used in the experiments presented in Fig. 3 (right-hand column) were collected from the same site in June 1994. Seeds of M. commutatum were collected in June 1992 from a burned pine forest in Avlona, Attica ( $480 \mathrm{~m}$ a.s.l.) during the first postfire year. Seeds of $M$. weissii and the three lots of $M$. neglectum used in the experiment reported in Table 1 were collected in Karpathos and Crete and were kindly provided by the Botanic Garden of Berlin. The average, air-dry seed weights for $M$. comosum, $M$. commutatum and $M$. weissii were, respectively: $5.8 \pm$ $0.1(n=50), 2.6 \pm 0.1(n=50)$ and $4.7 \pm 0.3 \mathrm{mg}(n=9)$. The mean seed weights for the two lots of $M$. neglectum (1991 and 1994) were $4.3 \pm 0.1(n=50)$ and $2.9 \pm 0.1 \mathrm{mg}(n=50)$, respectively. The seeds were stored in light- and waterproof plastic boxes, at room temperature $\left(20 \pm 5^{\circ} \mathrm{C}\right)$. Experiments with $M$. comosum and M. neglectum shown in Figs 1 and 2 and the lefthand column of Fig. 3 were performed after 3 months of storage, while those in the right-hand column of Fig. 3 were performed after 2 years of storage; experiments with $M$. commutatum (Figs 1 and 3) were performed after 3.5 years of seed storage.

Nomenclature follows Tutin et al. (1980), and distribution data are based on both Flora Europaea (Tutin et al., 1980) and Flora of Turkey and the East Aegean Islands (Davis and Stuart, 1984).

\section{Germination conditions}

Germination tests were performed in glass Petri dishes $(7 \mathrm{~cm}$ in diameter) lined with two filter-paper discs and moistened with $3 \mathrm{ml}$ of distilled water. The criterion of germination was visible radicle protrusion and, after each count, germinated seeds were discarded. The tests were terminated when no additional seeds germinated. All manipulations of imbibed seeds were carried out under a dim, green safelight. Unless otherwise indicated, each value is the mean of five replicates of 25 seeds \pm standard error (SE). $\mathrm{T}_{50}$ is the time needed for $50 \%$ of the final germination value, and is calculated by linear interpolation from the two germination values closest to median germination. Chipping of $M$. comosum seeds was carried out under a stereomicroscope: seeds were handled with forceps and a sharp scalpel was inserted $0.5 \mathrm{~mm}$ deep into the radicle end of the seed; with a slight twist, part of the seed coat and a small section of the endosperm were cut away to expose (but not damage) the radicle.

For germination experiments in darkness, seeds were incubated within lightproof, metal containers in controlled temperature cabinets (Model BK 5060 EL, W.C. Heraeus $\mathrm{GmbH}$, Germany) where temperature was kept constant within $\pm 0.5^{\circ} \mathrm{C}$ of the value set. Seed germination experiments under various light regimes were performed in temperature- and lightprogrammable growth units (model GB48, Conviron, Controlled Environments, Winnipeg, Canada) equipped with a lamp canopy of 48 incandescent bulbs (Sylvania 50A19, 50 W, $277 \mathrm{~V}$ ) and 10 fluorescent tubes (Sylvania Cool White FR96T12/CW/VHO-235/1). In order to simulate the natural conditions encountered during November- 
January, temperature and light programmes were automatically changed according to the average climatic data (period 1955-1987) of the Athens Airport Meteorological Station (Thanos et al., 1991). In the experiments presented in Fig. 3, temperature and light programmes were updated every day (left) or every week (right-hand column), respectively. Temperature was programmed to change every $3 \mathrm{~h}$, and lights were turned on $30 \mathrm{~min}$ before official sunrise and off $30 \mathrm{~min}$ after official sunset, while both the quality and quantity of light were automatically adjusted several times during the 'day' (Thanos et al., 1991). Light measurements were made with a portable spectroradiometer (LI-1800, Li-Cor, Lincoln, NE, USA); calculations of flux densities and values of $\zeta$ and $\phi$ were made using a previously described software application (Thanos et al., 1994). White light (W) had a value of $\zeta(660 / 730 \mathrm{~nm}$ photon ratio) equal to 1.031 , while the phytochrome photostationary state ratio $(\phi=[\mathrm{Pfr}] /[\mathrm{Ptot}])$ was 0.635 , and the total photon flux density in the visible range $(400-800 \mathrm{~nm})$ was $124.9 \mu \mathrm{mol} \mathrm{m}^{-2} \mathrm{~s}^{-1}$. When this light was filtered through three sheets of Plexiglas filters (two blue, 627, and one red, 501, 3-mm thick each; Röhm GmbH, Germany) a 'canopy simulating', far-red-rich light (FR) was obtained. In this case, the values of $\zeta$, $\phi$, and total flux density $\left(\mu \mathrm{mol} \mathrm{m}^{-2} \mathrm{~s}^{-1}\right)$ were $0.001,0.039$ and 19.8 , respectively.

\section{Results}

The germination time courses at various constant temperatures, in the dark, as well as the effect of temperature on final, dark germination for $M$. comosum, $M$. neglectum and $M$. commutatum are illustrated in Fig. 1. Germination of M. comosum seeds occurred very slowly, at a rather narrow range of cool temperatures $\left(5-15^{\circ} \mathrm{C}\right)$, and it was sharply suppressed above $15^{\circ} \mathrm{C}$ in the dark. However, having imbibed at inhibitory temperatures for 1 month, ungerminated seeds were induced to germinate fully upon a subsequent transfer to the optimal temperature, $15^{\circ} \mathrm{C}$. In $M$. neglectum, both rate and final values of dark germination, as well as temperature range, were similar to those of $M$. comosum, with one significant exception: at $5^{\circ} \mathrm{C}$ germination was nil. Seeds unable to germinate at the suboptimal temperatures 20 and $25^{\circ} \mathrm{C}$ could be induced to germinate fully upon transfer to the optimal temperature $10^{\circ} \mathrm{C}(3$ months after onset of imbibition). Full recovery of germinability did not take place in seeds imbibing for 1 month at $5^{\circ} \mathrm{C}$ : final germination scored upon transfer to the optimal temperature was about $60 \%$. Seeds of $M$. commutatum germinated optimally at $10-20^{\circ} \mathrm{C}$, while germination was abruptly suppressed at 5 and $25^{\circ} \mathrm{C}$. Ungerminated seeds could be induced to germinate fully upon a subsequent transfer to the optimal temperature, $15^{\circ} \mathrm{C}$. On the basis of germination rate, $M$. commutatum germinated faster compared to the two other species, while its optimal temperature range was shifted to somewhat warmer values $\left(15-20^{\circ} \mathrm{C}\right)$.

In a preliminary attempt to investigate the role of seed coat on Muscari germination, dry seeds of $M$. comosum were chipped and then both chipped and intact (control) seeds were incubated in continuous darkness at $10^{\circ} \mathrm{C}$. Chipping resulted in only a slight increase of germination rate (by 3-4 d) (Fig. 2).

Data on seed germination under 'late autumn' Mediterranean conditions for $M$. comosum and $M$. neglectum (lot 1991) are presented on the left-hand side of Fig. 3. Seeds were imbibed in diurnally alternating temperatures; white light was applied during the warm, 'day' period. Both the duration of the photoperiod and the temperatures of 'day' and 'night' were chosen to simulate those naturally encountered during November-December. The quality of the white light was similar to that of daylight, but its flux density was approximately $10 \%$ of the latter. Nevertheless, virtually total inhibition of germination (final level: 10\%) was recorded for $M$. neglectum, while a considerable delay (c. 6 days) of germination was observed for $M$. comosum seeds. The pace of germination was shown once more to be slow for both species; germination started as the temperature gradually decreased and reached a favourable range. Furthermore, photoinhibition was obtained with a small number of seeds of $M$. weissii and three additional seed lots of M. neglectum (Table 1 ). In two out of three of the M. neglectum lots examined, germination under white light was considerably inhibited, while in $M$. weissii and the third lot of M. neglectum, a decrease of both the final extent and the rate of germination was recorded. When ungerminated seed samples of $M$. neglectum (those shown in the left-hand column of Fig. 3) that had remained under simulated natural conditions and diurnal alternations of white light and dark for 4 months ('November-February') were transferred to complete darkness at $10^{\circ} \mathrm{C}$, only a further $10 \%$ germinated. Therefore, prolonged imbibition under white light not only inhibited germination but also led to an induction of secondary dormancy.

In the experiment presented in the right-hand column of Fig. 3, seeds of $M$. comosum, M. neglectum (lot 1994) and M. commutatum were imbibed under weekly average temperatures simulating those encountered during December-January. Dark germination of the first two species was considerably faster under these quite colder, winter conditions when compared with the autumn ones shown in the left-hand column of Fig. 3. On the basis of germination speed, M. commutatum was once more demonstrated 

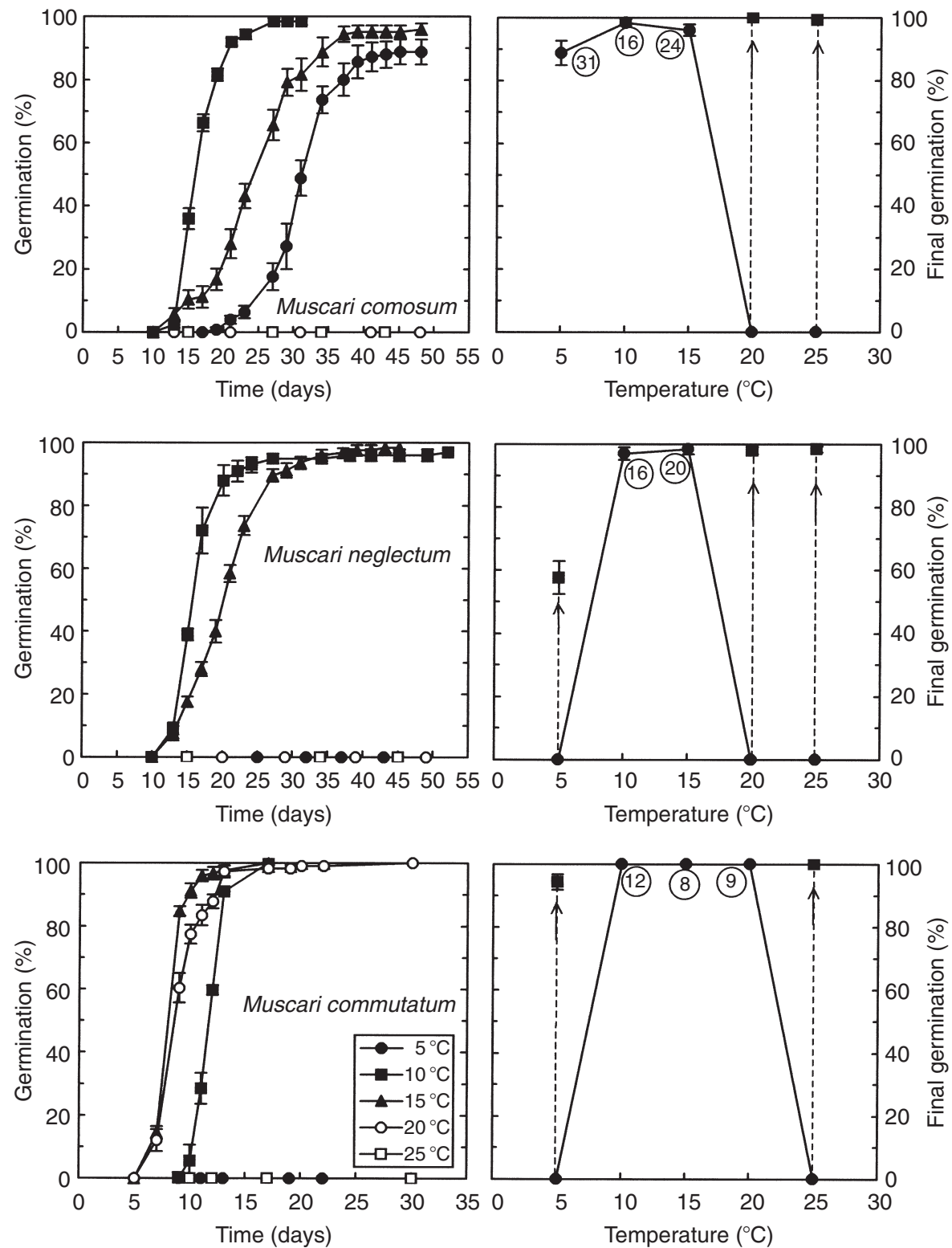

Figure 1. Time courses of seed germination (left-hand column) and final seed germination in continuous darkness (right-hand column), as a function of constant temperatures, for three species of Muscari. Circled numbers (right-hand column) are $\mathrm{T}_{50}$ values in days (time needed for $50 \%$ of final germination). The solid squares (right-hand column) correspond to final dark germination for the ungerminated seed samples (same samples shown in circles) upon transfer to the optimal temperature $\left(10^{\circ} \mathrm{C}\right.$ for $M$. comosum and M. neglectum and $15^{\circ} \mathrm{C}$ for $M$. commutatum). The transfer took place 1 month after onset of imbibition (in M. neglectum at 20 and $25^{\circ} \mathrm{C}$ : after 3 months). Vertical bars denote \pm SE.

to be the fastest among the three species. In all cases, far-red (canopy simulating) light, applied during the warm period, resulted in only a slight delay of germination compared to the dark control. Whereas a similar effect of white light (slight decrease of germination rate) was observed in M. comosum and $M$. commutatum, germination was dramatically inhibited in M. neglectum, reaching only c. $10 \%$. However, in this latter case no secondary dormancy was imposed; when ungerminated seeds that had remained under simulated natural conditions and diurnal alternations of white light and dark for about 1 month were transferred to $10^{\circ} \mathrm{C}$ in the dark, a further $80 \%$ germinated over a period of 30 days. 


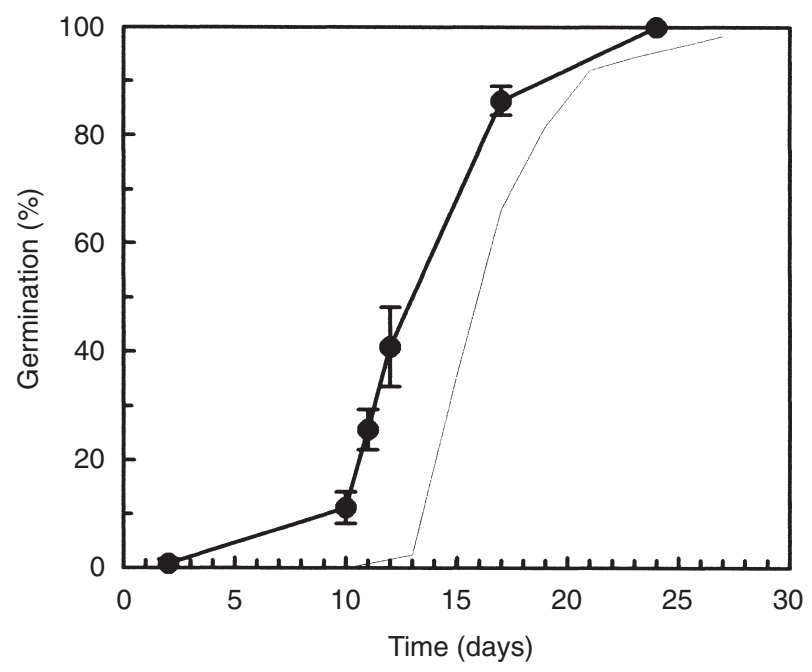

Figure 2. Time courses of germination for Muscari comosum seeds at $10^{\circ} \mathrm{C}$, in continuous darkness. (-) Seeds that have undergone chipping, i.e. part of the seed coat and a small section of the endosperm have been cut away to expose the embryonic radicle. The thin line (right) corresponds to untreated, intact seeds (cf. Fig. 1). Vertical bars denote \pm SE.

\section{Discussion}

\section{Temperature range and rate of germination}

The temperature range of dark germination in the Muscari species studied seems typically Mediterranean (Thompson, 1970; Thanos, 1993; Skordilis and Thanos, 1995) and is consistent with the species origin and distribution. Full germination took place at relatively cool temperatures $\left(5-20^{\circ} \mathrm{C}\right)$, with $M$. neglectum characterized by the narrowest range $\left(10-15^{\circ} \mathrm{C}\right)$, while germination of $M$. comosum and $M$. commutatum was additionally manifested at 5 and $20^{\circ} \mathrm{C}$, respectively. Due to the limited number of seeds, $M$. weissii was tested only at $15^{\circ} \mathrm{C}$, where full germination was obtained with a $\mathrm{T}_{50}$ value of 14 days (Table 1). On the basis of germination speed, the optimal temperature was $10^{\circ} \mathrm{C}$ for $M$. comosum and $M$. neglectum and $15^{\circ} \mathrm{C}$ for $M$. commutatum. Although the temperature of $15^{\circ} \mathrm{C}$ is frequently recorded as optimal among species growing in regions with a Mediterranean climate, the particularly cool temperature of $10^{\circ} \mathrm{C}$ found in the present study is rather unusual. A similar case is that of the liliaceous geophyte, Chionodoxa lochiae, where germination took place exclusively at $10^{\circ} \mathrm{C}$ with a $T_{50}$ value of 53 days (Kadis, 1995). The low temperature optima for manifestation of germination were also demonstrated in the experiments carried out under simulated natural conditions (Fig. 3), where germination took place only after the temperature decreased and matched the favourable range. All species were additionally characterized by a slow germination rate, with $T_{50}$ values ranging between 8 and 24 days under optimal conditions. Having imbibed at warm inhibitory temperatures, seeds of $M$. comosum, $M$. neglectum and $M$. commutatum were able to germinate fully upon transfer to the optimum temperature in the dark. However, the chilling temperature of $5^{\circ} \mathrm{C}$ had diverse effects: slight suppression of germination in M. comosum and full inhibition for $M$. commutatum and $M$. neglectum. In the latter species, seeds that had imbibed for 1 month at $5^{\circ} \mathrm{C}$ germinated up to only $60 \%$ upon subsequent transfer to the optimal temperature of $10^{\circ} \mathrm{C}$ (Fig. 1), whereas after prolonged imbibition ( 3 months at $\left.5^{\circ} \mathrm{C}\right)$, no germination took place upon transfer to the optimal temperature. When a tetrazolium test was applied, these ungerminated seeds were not stained, implying a loss of viability due to prolonged exposure to chilling temperatures. A similar adverse effect by prolonged chilling has been reported in the typical Mediterranean pine, Pinus halepensis (Skordilis and Thanos, 1995), as well as in the endemic geophyte of Cyprus, Scilla morrisii (Kadis, 1995).

A 'Mediterranean' temperature range of germination, similar to the one found in the present study, has been recorded in the Greek endemic, maritime geophyte, Allium staticiforme $\left(10-20^{\circ} \mathrm{C}\right.$ : Thanos et al., 1991; Delipetrou, 1996), as well as in the endemic plants of Cyprus, $A$. willeanum and $A$. autumnale $\left(10-15^{\circ} \mathrm{C}\right.$ : Skordilis and Georghiou, personal communication). Likewise, in three endemic and endangered geophytes of Cyprus (Scilla morrisii, Crocus hartmannianus and C. cyprius), germination took place at 10 and $15^{\circ} \mathrm{C}$ in the first two species and only at $10^{\circ} \mathrm{C}$ in the latter. In all cases the pace of germination was notably slow, with $\mathrm{T}_{50}$ values ranging from 30 to 60 days (Kadis, 1995). Finally, data on germination as a function of temperature in geophytes of the Negev Desert highlands (Israel) are in agreement with the results of the present study $\left[10-20^{\circ} \mathrm{C}\right.$ for Tulipa systola, Bellevalia eigii and $B$. desertorum (Boeken and Gutterman, 1990); $10-15^{\circ} \mathrm{C}$ for Allium truncatum and A. rothii (Gutterman et al., 1995)].

\section{Timing of germination}

The Mediterranean climate is characterized by a considerable unpredictability of temperature and precipitation. Water availability, in particular, is extremely variable, both within a single growing season and among consecutive years. The present experimental results (low germination rate and the requirement of a narrow range of cool temperatures) suggest that field germination of Muscari seeds is 

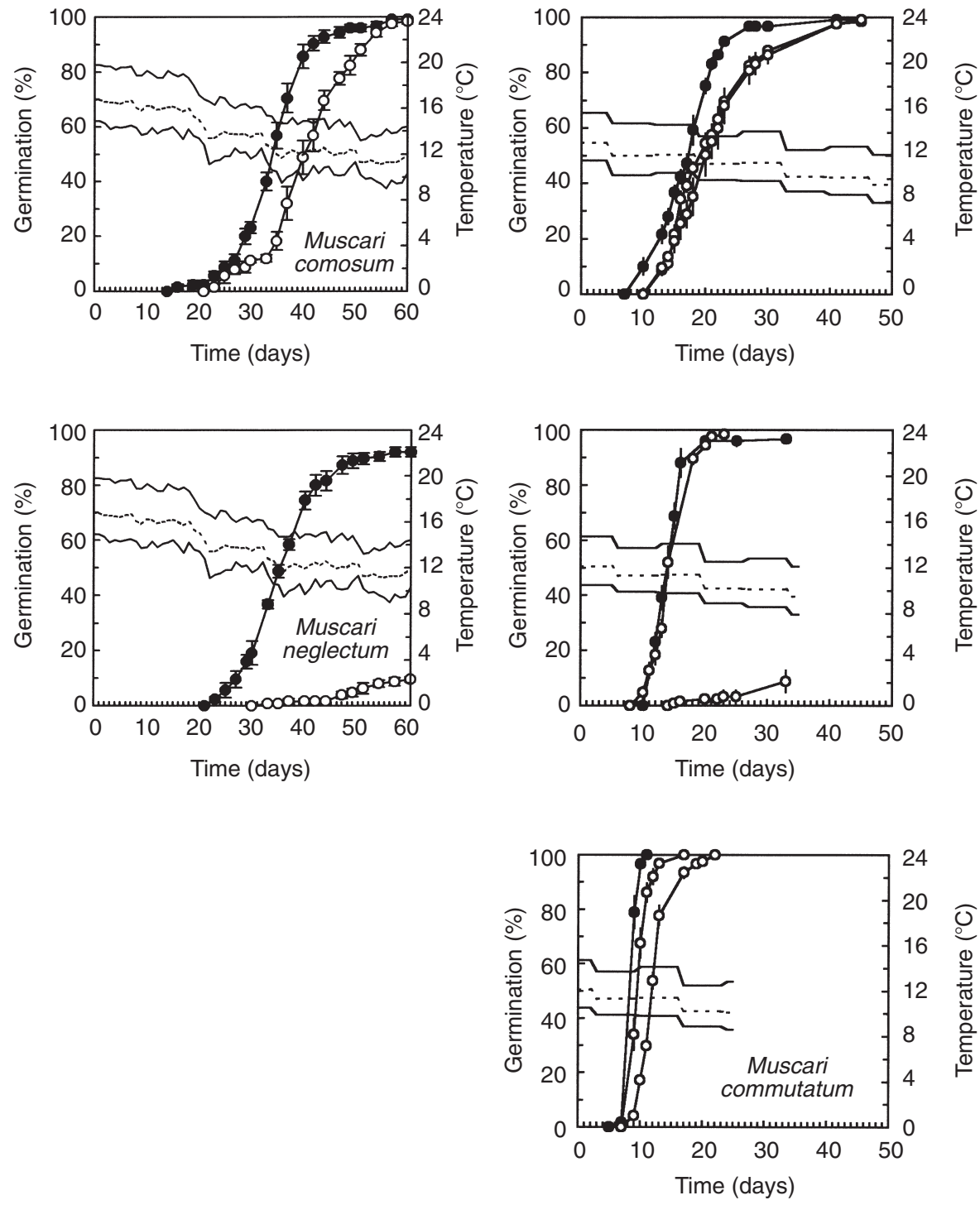

Figure 3. Germination time courses for three species of Muscari under simulated 'November-December' conditions (left-hand column; time 0 corresponds to ' 1 November') and 'December-January' conditions (right-hand column; time 0 corresponds to ' 1 December' for the upper diagram and '15 December' for the other two). Lines represent average values for daily (left-hand column) or weekly (right-hand column) temperatures (upper and lower solid lines: max. and min.; stippled line: mean). Solid circles, continuous darkness; open and grey circles, white light/dark and far-red/dark diurnal alternations, respectively. Vertical bars denote \pm SE.

tuned to take place well into the rainy season, in early winter, and provided that a quite lengthy, uninterrupted water supply is ensured. Such a 'delay mechanism' is considered an advantageous ecological adaptation towards the unpredictable rainfall pattern during the start of the rainy period in the Mediterranean climate (Thanos et al., 1995).

Moreover, when higher temperatures coupled with water availability happen to prevail, germination is inhibited; however, no secondary dormancy is imposed and, with a subsequent decrease of temperatures, germination can eventually take place (depending, of course, upon water supply). On the other hand, dry winter spells interrupting seed imbibition, in combination with the considerably slow pace of germination, may suppress radicle emergence in a fraction of the seed population, postponing germination until the next rainy season. Thus, it can be postulated that buried seeds of the Muscari species examined in the present study can 
Table 1. Final seed germination (\%) and germination rate $\left(\mathrm{T}_{50}\right)$ of Muscari weissii and three lots of $M$. neglectum, at $15^{\circ} \mathrm{C}$. $\mathrm{T}_{50}$ is the time needed for $50 \%$ of the final germination. In all cases one sample of 25 seeds was used except for M. neglectum, Chania $(n=50)$

\begin{tabular}{lrrrrrr}
\hline & \multicolumn{2}{c}{ Dark } & & \multicolumn{2}{c}{ Continuous white light } \\
\cline { 2 - 3 } \cline { 5 - 6 } & $\%$ & $\mathrm{~T}_{50}$ (days) & & $\%$ & $\mathrm{~T}_{50}$ (days) \\
\hline M. weissii (Karpathos) & 100 & 14 & & 56 & 36 \\
M. neglectum (Chania) & 100 & 17 & & 80 & 24 \\
M. neglectum (Lasithi) & 96 & 15 & & 8 & $\approx 40$ \\
M. neglectum (Karpathos) & 80 & 16 & & 24 & $\approx 50$ \\
\hline
\end{tabular}

persist in the soil (in the absence of appropriate cues), and germination can be distributed over more than one year. This hypothesis may well explain the observation by Theophrastus that $M$. comosum seedlings emerge in two consecutive years (HP 7.13.5). Similarly, seeds of Muscari pulchellum subsp. clepsydroides sown in a greenhouse in August were reported (Karlén, 1984) to start germinating in January and reach a final percentage of $51.2 \%$ at the end of April, while an additional $6.4 \%$ were found to germinate in the following 2 years. Finally, in Muscari subgenus Leopoldia, c. $50 \%$ of the seeds from intraand interspecific crosses germinated during the first year and another 20\% during the second (Bentzer, 1973).

\section{The role of the seed coat}

Chipping performed at a particular spot (point of radicle emergence) proved the most effective pretreatment for full germination in four liliaceous species, namely Muscari atlanticum, Allium ursinium, Anthericum liliago and Asphodelus tenuifolius (Newman, 1980). In the present study, chipping of $M$. comosum seeds resulted only in a slight enhancement of germination rate, since no primary dormancy was present. Therefore, the seed coat does not seem to be associated with the delay of germination in darkness, observed in the present study, as a factor of either water impermeability and/or mechanical restriction to radicle protrusion. Conversely, a quite plausible suggestion that merits further research is the postmaturation growth requirement of Muscari embryos, which are small, linear and apparently underdeveloped, as observed previously in many species of Liliaceae (Baskin and Baskin, 1998).

\section{The role of light}

Far-red light caused only a slight delay of germination in $M$. comosum, M. neglectum and $M$. commutatum, suggesting that germination in the field is feasible even under dense leaf canopies. On the other hand, white light, simulating daylight in duration and quality, resulted in a decrease of germination rate in $M$. comosum and $M$. commutatum. Moreover, in M. weissii and M. neglectum a marked inhibition was observed, suggesting that under natural conditions germination of seeds exposed to direct sunlight, in gaps or open areas, is considerably restricted in the former species and almost totally inhibited in the latter. Furthermore, imbibition of $M$. neglectum seeds for a relatively long period under this unfavourable light regime leads to the induction of a secondary dormancy (photodormancy).

The inhibitory role of white light in the germination of geophytes has been demonstrated in several other cases: Allium staticiforme (under 'natural' white light, Thanos et al., 1991; under white light/dark diurnal alternations, Delipetrou, 1996), A. truncatum and $A$. rothii (under naturally fluctuating temperatures, Gutterman et al., 1995), Bellevalia brevipedicellata (under continuous white light, Delipetrou, 1996) and in Pancratium maritimum (at all temperatures suitable for germination, Keren and Evenari, 1974; under white light/dark diurnal alternations, Delipetrou, 1996).

\section{The role of fire}

The seeds of $M$. comosum, $M$. neglectum and $M$. commutatum of the present study were collected from populations thriving in recently burned areas. However, no primary dormancy was found and the germination took place without any fire-related stimuli. Similarly, a study of Californian and South African geophytes revealed a lack of fire-stimulated germination (Keeley and Bond, 1997). Germination of heat-treated seeds of two liliaceous species, Calochortus splendens (Keeley and Keeley, 1987) and Zigadenus fremontii (Keeley et al., 1985), was decreased by $25 \%$ or more (Baskin and Baskin, 1998). On the other hand, geophytes are widely distributed in all mediterraneanclimate regions, and many of them flower prolifically 
after fire and recruit seedlings in the following years. $M$. comosum, M. neglectum and $M$. commutatum were recorded as common species in a burned Pinus halepensis forest of Mt. Parnes, Attica, during the initial (3-year long) postfire period (Thanos et al., 1996). Thus, in fire-prone ecosystems, survival of Muscari species is due to resprouting, but seedling recruitment seems to take place very early in the postfire succession through a substantial increase of reproductive activity, possibly the result of reduced competition.

\section{Acknowledgement}

We thank the Botanic Garden of Berlin for providing seeds for the present study.

\section{References}

Baskin, C.C. and Baskin, J.M. (1998) Seeds. Ecology, biogeography, and evolution of dormancy and germination. San Diego, Academic Press.

Bentzer, B. (1969) Chromosome morphology in Aegean populations of Leopoldia Parl. (Liliaceae). Botaniska Notiser 122, 457-480.

Bentzer, B. (1972a) Structural chromosome polymorphism in diploid Leopoldia weissii (Freyn) Freyn ex Heldr. (Liliaceae). Botaniska Notiser 125, 180-185.

Bentzer, B. (1972b) Variation in the chromosome complement of Leopoldia comosa (L.) Parl. (Liliaceae) in the Aegean (Greece). Botaniska Notiser 125, 406-418.

Bentzer, B. (1973) Taxonomy, variation and evolution in representatives of Leopoldia Parl. (Liliaceae) in the southern and central Aegean. Botaniska Notiser 126, 69-132.

Boeken, B. and Gutterman, Y. (1990) The effect of temperature on seed germination in three common bulbous plants of different habitats in the Central Negev Desert of Israel. Journal of Arid Environments 18, 175-184.

Dalgic, G. (1991) Cytotaxonomical studies on the genus Muscari in European Turkey. Botanika Chronika 10, 819-825.

Davis, P.H. and Stuart, D.C. (1984) Muscari Miller. pp. 245-263 in Davis, P.H. (Ed.) Flora of Turkey and the East Aegean Islands. Vol. 8. Edinburgh, Edinburgh University Press.

Delipetrou, P. (1996) Ecophysiology of seed germination in maritime plants with emphasis on the action of light (in Greek). PhD thesis, University of Athens, Athens, Greece.

Garbari, F. (1984) Some karyological and taxonomic remarks on the Italian Muscari (Liliaceae). Webbia 38, 139-164.

Gutterman, Y., Kamenetsky, R. and Van Rooyen, M. (1995) A comparative study of seed germination of two Allium species from different habitats in the Negev Desert highlands. Journal of Arid Environments 29, 305-315.

Kadis, C.C. (1995) On the reproductive biology of the strictly protected plants of Cyprus (in Greek). PhD thesis, University of Athens, Athens, Greece.
Karlén, T. (1984) Muscari pulchellum (Liliaceae) and associated taxa in Greece and W. Turkey. Willdenowia 14, 89-118.

Keeley, J.E. and Bond, W.J. (1997) Convergent seed germination in South African fynbos and Californian chaparral. Plant Ecology 133, 153-167.

Keeley, J.E. and Keeley, S.C. (1987) Role of fire in the germination of chaparral herbs and suffrutescents. Madroño 34, 240-249.

Keeley, J.E., Morton, B.A., Pedrosa, A. and Trotter, P. (1985) Role of allelopathy, heat and charred wood in the germination of chaparral herbs and suffrutescents. Journal of Ecology 73, 445-458.

Keren, A. and Evenari, M. (1974) Some ecological aspects of distribution and germination of Pancratium maritimum L. Israel Journal of Botany 23, 202-215.

Müller-Schneider, P. (1983) Verbreitungsbiologie (Diasporologie) der Blütenpflanzen. Veröffentlichungen des Geobotanischen Institutes der ETH, Stiftung Rübel, Zürich, 61, 1-226.

Müller-Schneider, P. (1986) Verbreitungsbiologie der Blütenpflanzen Graubündens. Veröffentlichungen des Geobotanischen Institutes der ETH 85, 1-263.

Negbi, M. (1989) Theophrastus on geophytes. Botanical Journal of the Linnean Society 100, 15-43.

Newman, P. (1980) Chipping for germination. The Garden 105, 297-298.

Skordilis, A. and Thanos, C.A. (1995) Seed stratification and germination strategy in the Mediterranean pines Pinus brutia and P. halepensis. Seed Science Research 5, 151-160.

Stuart, D.C. (1970) Chromosome numbers in the genus Muscari. Notes of the Royal Botanic Garden of Edinburgh 30, 189-196.

Thanos, C.A. (1993) Germination ecophysiology of Mediterranean aromatic plants. pp. 281-287 in Côme, D.; Corbineau, F. (Eds) Proceedings of the fourth international workshop on seeds. Basic and applied aspects of seed biology. Paris, ASFIS.

Thanos, C.A., Georghiou, K., Douma, D.J. and Marangaki, C.J. (1991) Photoinhibition of seed germination in Mediterranean maritime plants. Annals of Botany 68, 469-475.

Thanos, C.A., Georghiou, K. and Delipetrou, P. (1994) Photoinhibition of seed germination in the maritime plant Matthiola tricuspidata. Annals of Botany 73, 639-644.

Thanos, C.A., Kadis, C.C. and Skarou, F. (1995) Ecophysiology of germination in the aromatic plants thyme, savory and oregano (Labiatae). Seed Science Research 5, 161-170.

Thanos, C.A., Daskalakou, E.N. and Nikolaidou, S. (1996) Early post-fire regeneration of a Pinus halepensis forest on Mount Párnis, Greece. Journal of Vegetation Science 7, 273-280.

Theophrastus Enquiry into plants. Vols I and II. Hort, A.F. (translator, 1916 and 1926). Cambridge, Mass. and London, Harvard University Press and William Heinemann Ltd.

Theophrastus De Causis Plantarum. Volumes I-III. Einarson, B. and Link, G.K.K. (translators, 1976 and 1990). London 
and Cambridge, Mass., William Heinemann and Harvard University Press.

Thompson, P.A. (1970) Characterization of the germination response to temperature of species and ecotypes. Nature 225, 827-831.

Tutin, T.G., Heywood, V.H., Burges, N.A., Moore, D.M., Valentine, D.H., Walters, S.M. and Webb, D.A. (Eds) (1980) Flora Europaea, Vol. 5. Cambridge, Cambridge University Press.
Valdés, B. and Mejias, J.A. (1988) Contribución al estudio de la biología de la reproducción de las especies españolas de Muscari (Liliaceae). Lagascalia 15, 95-103.

Received 7 February 2002

accepted after revision 19 April 2002

(C) CAB International 2002 